\title{
ШЛАКИ КОМБИНАТА «ПЕЧЕНГАНИКЕЛЬ» В РЕШЕНИИ ЭКОЛОГИЧЕСКИХ ЗАДАЧ
}

Горбачева Т.Т. ${ }^{1}$, Иванова Л.А. ${ }^{2}$, Макаров Д.В. ${ }^{3}$

${ }^{1}$ ФИЦ Кольский Научный Центр PAH, podzol_gorby@mail.ru

${ }^{2}$ Полярно-альпийский ботанический сад-институт Кольского Научного Центр им. Н.А. Аврорина;

${ }^{3}$ Институт проблем промышиленной экологии Севера ФИЦ Кольский Научный Центр РАН

Активная эксплуатация минерально-сырьевой базы Мурманской области способствовала формированию на ее территории техногенных месторождений, к которым, согласно определению, относят скопления вторичных минеральных ресурсов, образовавшихся в результате складирования отходов производства или потребления. В отличие от естественных (геогенных) месторождений они характеризуются пониженным содержанием полезного компонента, поэтому их разработка зачастую признается экономически нецелесообразной. Одними из таких техногенных месторождений на территории Мурманской области являются отвалы шлаков плавильного цеха комбината «Печенганикель» АО «Кольская ГМК», формирование которых началось в 1945 г. В настоящее время в шлаковых отвалах накоплено более 45 млн.т. сырья [8]. Применение этих вторичных минеральных ресурсов весьма ограничено - только незначительное количество шлаков применяют в качестве заполнителя закладочных смесей на рудниках комбината и при отсыпке дорог.

Оценке экологической опасности шлаков «Печенганикеля» посвящен ряд работ $[5,7,8]$. Потенциальную токсичность шлаков связывают с их трансформацией под воздействием кислотообразующих компонентов атмосферных осадков и минерализованных шахтных вод, сбрасываемых на шлакоотвал. Эксперименты в динамическом режиме показали достаточно интенсивное выщелачивание цветных металлов и железа - как из шлаков текущего производства, так и из лежалых шлаков [8].

Следует подчеркнуть, что в целом по РФ металлургические шлаки и продукты их переработки находят широкое применение, в т.ч. для решения экологических задач [1], а именно:

(1) нейтрализации кислых шахтных вод при прекращении добычи руд;

(2) очистке грунтовых вод от токсичных загрязнителей;

(3) выработке твердеющих закладочных смесей при подземной отработке месторождений и закладке карьерных выемок;

(4) создание буферного или дренажного слоя при проведении рекультивационных работ;

(5) замене почвенного покрова или известковании почвогрунтов в биологическом этапе рекультивации.

Пионерами выбора путей переработки шлаков металлургических производств на территории Мурманской области явились сотрудники ИППЭС КНЦ РАН Зосин А.П. и Приймак Т.И. [3]. Авторами предложен метод получения геополимерных материалов на основе шлаков комбината «Печенганикель», которые могут быть применены в качестве сорбентов для очистки сточных вод от тяжелых металлов. Проведенные авторами исследования сорбции катионов никеля, кобальта, меди на шлакосиликатном сорбенте показали, что он обладает полифункциональными свойствами, обеспечивающими высокую сорбционную емкость в отношении катионов тяжелых металлов (никеля, меди, кобальта) на уровне 1.5-1.6 мг-экв/г [4].

При малых масштабах переработки отходов самым простым и малозатратным способом консервации техногенных месторождений является отведение их под самозарастание, однако этот способ оправдан только для техногенных субстратов с благоприятными эдафическими свойствами. Изза низкого содержания органического вещества отвалы техногенных отходов региона имеют неблагоприятные эдафические свойства, обусловливающие их низкий или несбалансированный питательный режим. Это связано с тем, что в процессе разработки месторождений Мурманской области никаких проектных решений относительно снятия плодородного и потенциально-плодородного слоев почвы с площади ведения горных работ с их последующим складированием не предусматривалось. Такой подход обусловлен маломощностью органогенных горизонтов в нативных почвах региона (менее 10 см, ГОСТ 17.4.3.02-85). Основным этапом при проведении рекультивации грунтов 
с низким питательным режимом является землевание с последующим созданием растительного покрова (дернины) из многолетних трав, устойчивых как к жестким климатическим условиям Крайнего Севера, так и продолжающейся аэротехногенной нагрузке. Однако это - дорогой и весьма трудозатратный способ, а изъятие плодородного слоя с других территорий переводит их в категорию нарушенных. В качестве альтернативы авторами данной работы предложен вариант биотехнологии, включающий в себя комбинацию двух методов:

1. Применение смешанного мелиоранта/почвозаменителя (вермикулит + шлак), обладающего удобрительным эффектом;

2. Посев толерантных видов растений.

Цель работы: оценка пригодности шлаков «Печенганикеля» для химической мелиорации/консервации, потенциально применимой как для тела отвала, так и территорий, прилегающих к отвалу.

Шлаки металлургических производств давно и весьма широко применяются в РФ. Так, из сталеплавильных шлаков производят шлако-известковые и шлако-фосфорные удобрения. В практике сельского хозяйства действует ТУ 14-11-240-88 «Шлак сталеплавильный для химической мелиорации и удобрения почв». Такой шлак содержит значительное количество оксида кальция при относительно меньшей доле оксида кремния и наличии микроэлементов в своем составе, что делает вполне привлекательным его использование для известкования кислых почв взамен извести. Однако применимость шлаков медно-никелевых производств ограничена их потенциальной токсичностью для растений. О токсичности шлаков, как правило, судят либо по результатам длительного выщелачивания, либо опытов по влиянию на материал шлака таких активных сред, как разбавленная серная кислота или органические экстрагенты.

Химический состав лежалых шлаков комбината «Печенганикель» следующий (\%): $\mathrm{K}_{2} \mathrm{O}-0.72$, $\mathrm{Fe}_{2} \mathrm{O}_{3}-10.03, \mathrm{FeO}-26.55, \mathrm{CaO}-3.16, \mathrm{MgO}-10.39, \mathrm{Na}_{2} \mathrm{O}-1.12, \mathrm{Al}_{2} \mathrm{O}_{3}-6.81, \mathrm{MnO}-0.13, \mathrm{TiO}_{2}-0.80$, $\mathrm{SiO}_{2}-40.53$ [5]. Сопоставление состава шлаков текущего производства и лежалых шлаков по данным, приведенным в упомянутой работе, свидетельствует о том, что выраженной потери большинства элементов в шлаке при его длительном хранении (до 15 лет) в отвалах не наблюдается, однако имеет место незначительное выщелачивание $\mathrm{Mg}$. Эта особенность шлаков в сочетании с наличием в их составе основных питательных элементов ( $\mathrm{K}, \mathrm{Ca}, \mathrm{Mg}$ ) и высоким содержанием $\mathrm{Fe}, \mathrm{Al}, \mathrm{Si}$, являющихся типоморфными почвенными элементами, позволяют рассматривать шлаки как потенциальный химический мелиорант пролонгированного действия и возможный компонент субстрата - почвозаменителя.

\section{Материалы и методы исследования}

В 2012 г. были проведены лабораторные эксперименты по созданию растительного покрова на минеральных грунтах лежалых шлаков, отобранных на шлакоотвале комбината «Печенганикель». Пробоподготовка высушенных до воздушно-сухого состояния образцов шлаков проводилась по общепринятым методикам почвенных анализов, включающим рассев на сите 1 мм, определение гигроскопической влажности, экстракцию аммонийно-ацетатным буфером $(\mathrm{pH}=4.65$, соотношение грунт: экстрагент 1:2.5). Содержание доступных форм элементов в вытяжке определяли методами атомно-эмиссионной и атомно-абсорбционной спектрометрии, $\mathrm{pH}$ - потенциометрическим методом, Р - методом Ватанабэ по интенсивности синей окраски восстановленного фосфорномолибденового комплекса. Анализ шлаков проводился в пяти повторностях.

Оценка шлаков по их пригодности для рекультивации выполнена в соответствии с требованиями ГОСТ 17.5.1.03-86. «Охрана природы. Земли. Классификация вскрышных и вмещающих пород для биологической рекультивации» на основании следующих показателей: $\mathrm{pH}$ водной вытяжки, содержание подвижных форм Al, сумма фракций менее 0.01 мм.

По результатам анализов проведено сопоставление химического состава подвижных форм тяжелых металлов с требованиями ГН 2.1.7.2041-06. Указанные Гигиенические нормативы устанавливают санитарно-эпидемиологические требования, в том числе критерии безопасности и/или безвредности факторов среды обитания для человека. 


\section{Результаты и обсуждение}

\section{Гранулометрический состав шлаков}

Доминирующее положение в составе шлаков занимают фракции 1.0-2.0 мм (более 38\%) и 0.5-1 мм (более 26\%). Доля самой тонкодисперсной фракции ( $<0.1$ мм) не превышает $0.4 \%$ [5]. В соответствии с ГОСТ 17.5.1.03-86 породы признаются пригодными в биологической рекультивации без улучшения физических свойств, если содержание фракции $<0.01$ мм (глинистой) составляет от 10 до 75\%. В.В. Миронов [6] установил предельный нижний уровень содержания глинистых фракций в песках, при котором возможно развитие древесных и кустарниковых пород, как величину в 4\%. Шлаки «Печенганикеля» характеризуются очень низкой долей благоприятной для рекультивации фракции $<0.1$ мм, что позволяет прогнозировать их слабую эффективность при применении без дополнительных кондиционеров.

\section{Оценка влажности шлаков}

По показателю гигроскопичности шлаки характеризуются низкими значениями, близкими к влажности завядания растений на техногенных землях Европейского Севера, лимитированной значениями 0.54-2.85\% [9]. Отсюда шлаки могут быть признаны малопригодными для биологической рекультивации и нуждающимися в обязательном кондиционировании водоудерживающими материалами, поскольку их влажность не превышает $3.4 \%$ [5].

\section{рН водной вытяжки}

Шлаки цветной металлургии в процессе выщелачивания формируют кислые растворы за счет окисления остаточных количеств сульфидов тяжелых металлов, в частности, железа. Однако оливины и пироксены, присутствующие в шлаке, оказывают кислотонейтрализующее действие на состав раствора [10]. В наших исследованиях рост кислотности водной вытяжки из шлаков не отмечен. Как показывают результаты, многокомпонентный минеральный состав шлаков оказывает буферирующее действие на кислотность водной вытяжки с поддержанием $\mathrm{pH}$ на уровне $6.64 \pm 0.02$ при допустимых пределах варьирования 5.5-8.4 согласно требованиям ГОСТ 17.5.1.03-86.

\section{Подвижные формы Al}

В соответствии с ГОСТ 17.5.1.03-86 признание техногенного субстрата пригодным к биологической рекультивации возможно при содержании подвижных форм Al не выше 0-30 мг/кг. Вариабельность содержания подвижных форм алюминия в шлаке $35 \pm 6$ мг/кг, т.е. в целом укладывается в допустимые пределы.

\section{Питательный статус илака как химического мелиоранта}

Валовое содержание химических элементов в лежалых шлаках Печенганикеля приведено выше. Содержание подвижных форм, определенное нами в ходе анализа шлаков, следующее (мг/ кг): $\mathrm{K}-8.4 \pm 0.3 ; \mathrm{Mg}-167 \pm 5 ; \mathrm{Ca}-39 \pm 7 ; \mathrm{P}-3.9 \pm 0.6 ; \mathrm{Mn}-1.3 \pm 0.3 ; \mathrm{Fe}-616 \pm 21 ; \mathrm{Cu}-5.6 \pm 0.3$; $\mathrm{Zn}-0.8 \pm 0.1 ; \mathrm{Ni}-18 \pm 1.7$. Наличие подвижных форм $\mathrm{Cu}$ и Ni незначительно превышает ПДК (с учетом кларка). Доля подвижных форм по отношению к валовому содержанию по всем элементам весьма низкая, что позволяет предположить пролонгированное действие шлаков как химического мелиоранта, даже при применении в опытах такого высоко активного экстрагента, как аммонийноацетатный буфер. Для целей рекультивации и консервации шлакоотвалов это является обнадеживающим обстоятельством.

Выводы: Шлак медно-никелевого производства комбината «Печенганикель» имеет благоприятные характеристики для его использования в биологической рекультивации отвалов как компонента смешанного химического мелиоранта при условии добавок к нему водоудерживающих материалов, повышающих его влагоемкость. 


\section{Литература}

1. Антонинова Н.Ю., Шубина Л.А. Использование техногенных отходов ГМК в природоохранных целях на предприятиях ГМК // Экология и промышленность России. 2015. №10. С. 38-41.

2. ГОСТ 17.5.1.03-86. «Земли. Классификация вскрышных и вмещающих пород для биологической рекультивации».

3. Зосин А.П., Приймак Т.И. Адсорбционно-активные материалы на основе твердеющих минеральных дисперсий в управлении движением отходами переработки горнорудного сырья. Апатиты: КНЦ РАН, 1999. 249 c.

4. Зосин А.П., Приймак Т.И., Кошкина Л.Б., Маслобоев В.А. Адсорбенты на основе магнезиальножелезистных шлаков цветной металлургии для очистки технологических стоков от катионов цветных металлов // Вестник Мурманского государственного технического университета. 2008. Т. 11. № 3. С. 502-505.

5. Макаров Д.В., Потапов Д.С., Потапов С.С., Светлов А.В. Исследование экологической опасности и потенциальной возможности извлечения полезных компонентов из гранулированных шлаков комбината «Печенганикель» ОАО «Кольская ГМК» // Экология промышленного производства. 2013. № 2 (82). C. 54-58.

6. Миронов В.В. Экология хвойных пород при искусственном лесовозобновлении. М.: Лесная промышленность, 1977. $232 \mathrm{c}$.

7. Паршина М.В. Влияние процессов гипергенной метаморфизации техногенных массивов на степень их экологической опасности для окружающей среды // Зап. Горного института. 2009. Т. 180. С. 33-35.

8. Потапов Д.С., Светлов А.В., Потапов С.С., Меньшиков Ю.П., Нестеров Д.П., Макаров Д.В. Экспериментальное моделирование процессов выветривания разновозрастных шлаков медно-никелевого производства // Минералогия техногенеза. 2013. С. 38-49.

9. Федорец Н.Г., Соколов А.И., Шильцова Г.В., Германова Н.И., Крышень А.М, Антипина Г.С. Начальные стадии формирования биогеоценозов на техногенных землях Европейского Севера. Петрозаводск: Карельский научный центр РАН, 1999. 74 с.

10. Jambor J.L. Mine-waste mineralogy and mineralogical perspectives of acid-base accounting. In: Jambor J.L., Blowes D.W., Ritchie A.I.M. (Eds.) Environmental Aspects of Mine Wastes: Mineralogical Association of Canada, 2003.V. 31. P. 117-145. 